\title{
Rational Surface Modification of Carbon Nanomaterials for Improved Direct Electron Transfer-Type Bioelectrocatalysis of Redox Enzymes
}

\author{
Hongqi Xia ${ }^{1,2}$ (D) and Jiwu Zeng ${ }^{1,2, *}$ \\ 1 Key Laboratory of South Subtropical Fruit Biology and Genetic Resource Utilization (MOA), \\ Institute of Fruit Tree Research, Guangdong Academy of Agricultural Sciences, \\ Guangzhou 510640, China; hqixia@sina.cn \\ 2 Guangdong Province Key Laboratory of Tropical and Subtropical Fruit Tree Research, \\ Guangzhou 510640, China \\ * Correspondence: zengjiwu@gdaas.cn
}

Received: 27 October 2020; Accepted: 4 December 2020; Published: 10 December 2020

\begin{abstract}
Interfacial electron transfer between redox enzymes and electrodes is a key step for enzymatic bioelectrocatalysis in various bioelectrochemical devices. Although the use of carbon nanomaterials enables an increasing number of redox enzymes to carry out bioelectrocatalysis involving direct electron transfer (DET), the role of carbon nanomaterials in interfacial electron transfer remains unclear. Based on the recent progress reported in the literature, in this mini review, the significance of carbon nanomaterials on DET-type bioelectrocatalysis is discussed. Strategies for the oriented immobilization of redox enzymes in rationally modified carbon nanomaterials are also summarized and discussed. Furthermore, techniques to probe redox enzymes in carbon nanomaterials are introduced.
\end{abstract}

Keywords: direct electron transfer; bioelectrocatalysis; orientation; carbon nanomaterials; surface modification

\section{Introduction}

Bioelectrocatalysis, which couples an enzymatic catalysis with an electrode reaction and thereby transforms the chemical energy of the reactant into electrical energy (or vice versa), plays an important role in various applications, including biological fuel cells [1], biosensors [2], and bio-electrosynthesis [3] Redox enzymes in solutions usually show significantly high catalytic efficiency toward their natural substrates. However, enzymes immobilized on the surface of a solid electrode usually do not enable sufficient electron transfer kinetics between the redox-active sites and the support owing to electrical insulation of the redox-active site by the surrounding polypeptides.

In general, mechanisms of electron transfer between enzymes and electrodes are classified into mediated electron transfer (MET) and direct electron transfer (DET) [4] (Figure 1). In an MET-type system, an extrinsic redox-active species, referred to as a mediator, is utilized to shuttle electrons between the enzyme redox site and an electrode [5]. In this case, the redox enzyme catalyzes the oxidation or reduction of the mediator as a co-substrate. The reverse transformation (regeneration) of the mediator occurs reversibly or quasi-reversibly on the electrode surface. The use of small, low-molecular-weight electron mediators that require low overpotentials can be beneficial because they can enable rapid electron transfer between an enzyme and an electrode with low power loss. However, the cost, stability, selectivity, and ability to exchange electrons in the immobilized state of such mediators must also be considered. In contrast, in a DET-type system, fast electron transfer to or from a solid electrode occurs through the intrinsic electron relay system in the protein [6] (such as 
a series of ion-sulfur clusters [7], hemes [8], copper atoms [9], or some amino acid residues [10,11]). Accordingly, the electrode surface acts as a co-substrate of the redox enzyme, and the enzymatic and electrode reactions proceed simultaneously. From this viewpoint, a DET-type bioelectrocatalysis constructed with only an enzyme and an electrode is mostly an ideal system that provides high selectivity for electrochemical biosensors and a high cell voltage for enzymatic biofuel cells without a proton exchange membrane.

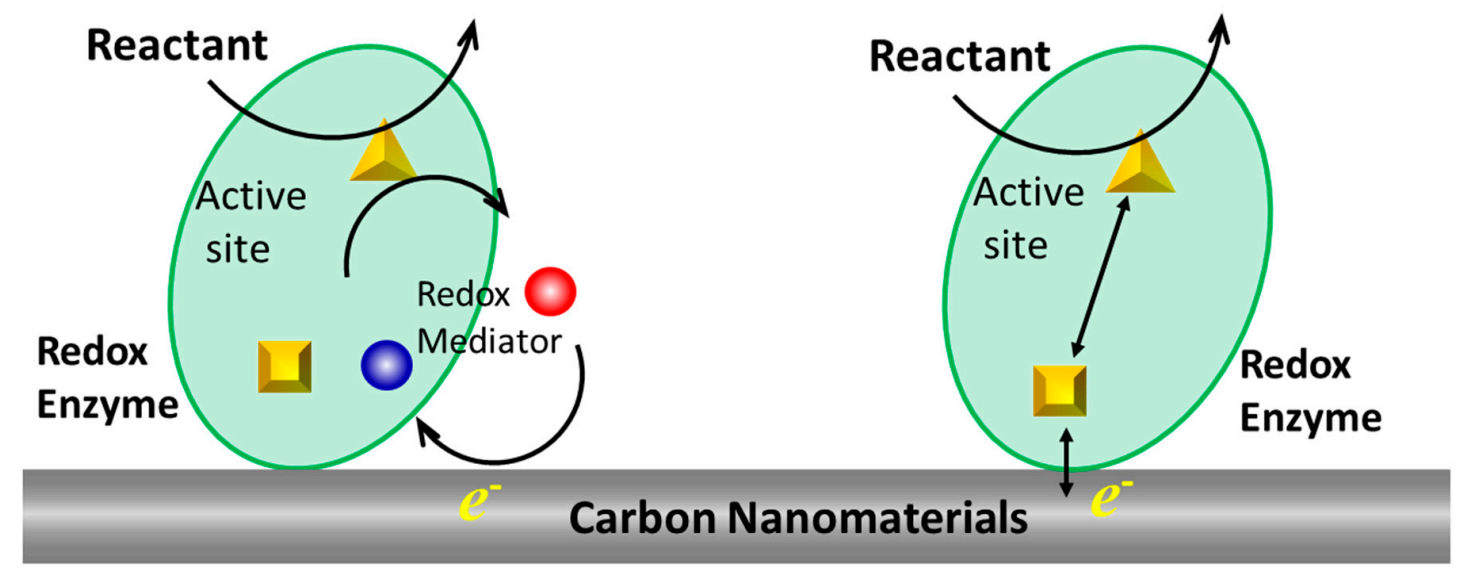

Figure 1. Schematic of electron transfer routes of (left) MET-type and (right) DET-type bioelectrocatalysis.

Over the past few decades, significant efforts have been devoted to improving the performance of DET-type bioelectrocatalysis, including protein engineering, electrode materials, and bio-interfacial engineering $[12,13]$. The interfacial electron transfer rate constant $(k)$, according to Macrus's theory $[14,15]$, is governed by the potential difference, re-organization energy, and most importantly, the distance between the active center of the enzymes and the electrode surface. The electron transfer rate constant between the redox site and the electrode decreases exponentially with increasing distance. Because redox enzymes are sizable proteins with anisotropic properties and their active sites are not always located in the central region, the distance between the active site and the electrodes should be varied according to the orientation of the enzymes when immobilizing at the electrode surfaces. Therefore, controlling the orientation of the enzyme on the electrode surface is a key factor in realizing a fast interfacial electron transfer [16,17].

Carbon nanomaterials, such as carbon nanotubes (CNTs), graphene, carbon nanoparticles, and their combinations thereof, have been widely utilized in DET-type bioelectrocatalysis owing to their high conductivity, chemical stability, and low cost. CNTs are nanowires constituted from one or more layers of seamlessly rolled graphene (single-walled and multi-walled CNTs, respectively) with large specific surface areas (in a precise sense, with large values for surface-to-weight ratio) and behave electrically as metals or as semiconductors [18]. Moreover, purified CNTs are usually electrochemically inert and do not exhibit voltametric response in the potential window commonly used [19]. In contrary to CNTs, graphene is a two-dimensional sheet of $\mathrm{sp}^{2}$ bonded carbon atoms possess unique properties, like ballistic conductivity, high specific surface area, and rapid heterogeneous electron transfer [20]. For example, it has been reported that the specific surface area of graphene sheets is frequently larger than that of single-walled CNTs. Unlike structurally more defined CNTs and graphene, structurally less-defined carbon nanoparticles are considered more economical than other carbon nanomaterials because they are produced commercially in bulk quantities and also often formed as waste byproducts during the formation of other nanomaterials, such as CNTs [21]. In addition to these intrinsic properties mentioned above, carbon nanomaterials can be easily modified for different purposes through various approaches, including diazonium grafting, amine electrochemical oxidation, and $\pi-\pi$ interactions. An increasing number of redox enzymes, including glucose dehydrogenase [22], fructose dehydrogenase (FDH) [23], cellobiose dehydrogenase [24], formate dehydrogenase ( $\mathrm{FoDH})$ [25], hydrogenase $\left(\mathrm{H}_{2}\right.$ ase), bilirubin 
oxidase (BOD), laccase (Lac) [26], cooper efflux oxidase (CueO) [27], and peroxidase [28], have been reported to be capable of DET at a suitable carbon nanomaterial-based electrode. Notably, although many researchers in the previous decades have claimed that glucose oxidase, a well-known enzyme utilized in glucose biosensors and biofuel cells, achieves a DET capability in carbon nanomaterials, recent studies have concluded that no evidence supports the idea that native glucose oxidase undergoes DET in carbon nanotubes or graphene [29-31]. Understanding the mechanisms and roles of carbon nanomaterials in direct biolectrocatalysis is essential to identifying whether a DET reaction occurs and for preparing a suitable platform for DET-type bioelectrocatalysis with a high performance.

In this mini review, we start with the significance of carbon nanomaterials in promoting direct bioelectrocatalysis of redox enzymes. The effects of the pore distribution and surface chemical properties of carbon nanomaterials on DET-type bioelectrocatalysis are emphasized. Following a summarization of the surface modification of carbon nanomaterials, the oriented immobilization of redox enzymes in rationally functionalized carbon nanomaterials via different strategies is reviewed. Techniques to probe the redox enzymes on the carbon nanomaterial surfaces are also described.

\section{Significance of Carbon Nanomaterials on Direct Bioelectrocatalysis}

\subsection{Effect of Pore Distribution}

The primary motivation of using carbon nanomaterials for direct electrocatalysis, at the early stage, is ascribed to the high enzyme loading because of its large specific surface area. Although we agree that enzyme loading is essential to the performance of direct bioelectrocatalysis, several recent studies have proposed that the microstructure and the surface physiochemistry of carbon nanomaterials also play important roles in DET-type bioelectrocatalysis. For example, carbon cryogels with a controlled average pore radii of 5-40 $\mathrm{nm}$ have been utilized for FDH immobilization [32]. It has been found that, although the estimated Brunauer-Emmett-Teller (BET) specific surface area of a carbon cryogel with an average pore radius of $40 \mathrm{~nm}$ is the smallest, the DET-type bioelectrocatalytic current of fructose oxidation in a carbon cryogel with an average pore radius of $40 \mathrm{~nm}$ is the highest $\left(\sim 5 \mathrm{~mA} \mathrm{~cm}{ }^{-2}\right)$, compared to those of carbon cryogels with radii of 5,11,16, and $26 \mathrm{~nm}$, which have higher BET specific surface areas. Similar results have been obtained for MgO-templated carbon nanomaterial electrodes using different redox enzymes, including FDH [33], $\mathrm{BOD}$ [34], and $\mathrm{H}_{2}$ ase [35]. Rather than a high specific surface area, carbon nanomaterials with suitable pore size distributions are apparently more essential for the DET-type bioelectrocatalysis of redox enzymes.

A theoretical model of a randomly oriented spherical enzyme adsorbed in a planar or three-dimensional electrode was proposed [36,37] (Figure 2). In that model, spherical pores with a radius close to that of the enzyme improves the interfacial electron transfer kinetics thanks to increased probability of orientations with a short distance during the interfacial electron transfer (Figure 2). This effect is referred to as the curvature effect of porous structures $[12,13]$. These porous structures can be found at the surface of mesoporous carbon materials or can be formed through primary carbon nanoparticle aggregation. For example, in a comparative study, three types of carbon materials-Ketjen Black EC300J (KB), Vulcan XC-72R (Vulcan), and high-purity exfoliated graphite J-SP (JSP)—were utilized as scaffolds for the DET-type bioelectrocatalysis of BOD [38]. The results show that the micropores at the JSP surface are highly effective for the DET-reaction of BOD, whereas gaps between several primary particles in the KB and Vulcan aggregates play important roles as scaffolds for MvBOD. 
A

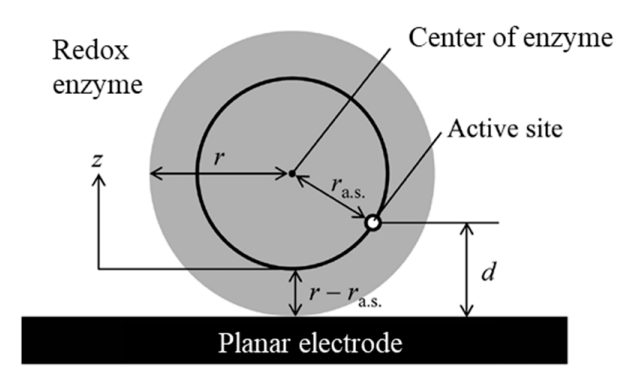

B

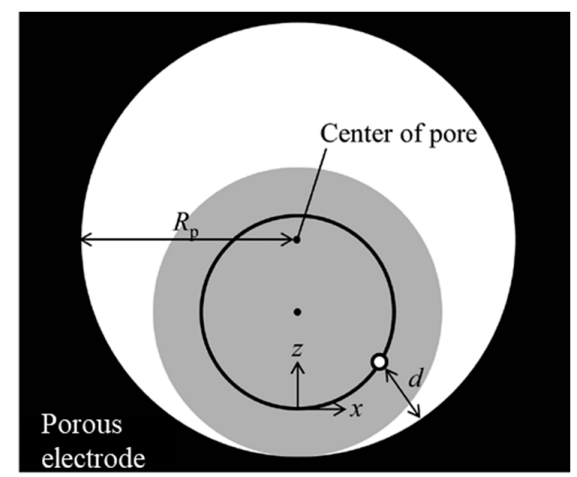

Figure 2. Schematic model of an adsorbed enzyme on (A) planar and (B) porous electrodes. Reprinted from [37]. Copyright (2016), with permission from American Chemical Society.

Notably, the optimization of carbon nanomaterials for DET-type bioelectrocatalysis requires balancing the ratio of macro-, meso-, and micropores for the construction of a hierarchical three-dimensional structure effective for the mass transport of an electrolyte solution and substrates as well as the penetration of enzymes into the nanostructures, and enhancing the interfacial electron transfer kinetics of macromolecular redox enzymes. The dispersion parameter of $\mathrm{H}_{2}$ ase in $\mathrm{MgO}$-templated carbon with a pore size of $35 \mathrm{~nm}$ is notably smaller than that in MgO-templated carbons with a pore size of $150 \mathrm{~nm}$ [35], which can be explained by the curvature effect [36,37], as mentioned above. However, the $\mathrm{H}_{2}$-oxidation bioelectrocatalytic current produced by $\mathrm{H}_{2}$ ase in $\mathrm{MgO}$-templated carbons with a pore size of $150 \mathrm{~nm}\left(\sim 450 \mu \mathrm{A} \mathrm{cm}^{-2}\right)$ is higher than that in MgO-templated carbons with a pore size of $35 \mathrm{~nm}$ $\left(\sim 50 \mu \mathrm{A} \mathrm{cm}^{-2}\right)$ owing to greater enzyme penetration in carbon with larger pores [35]. Furthermore, a hierarchical dual MgO-templated carbon, with a mixture of 33\% macropores $(150 \mathrm{~nm})$ and $67 \%$ mesopores $(40 \mathrm{~nm})$, was prepared for the DET-type bioelectrocatalysis of BOD [39]. The results show that the oxygen reduction current in dual MgO-templated carbon reached to around $10 \mathrm{~mA} \mathrm{~cm}{ }^{-2}$, which is much higher than that in a MgO-templated carbon electrode with only meso- or macro-porous structures $\left(\sim 5.6 \mathrm{~mA} \mathrm{~cm}^{-2}\right.$ or $\left.\sim 5.1 \mathrm{~mA} \mathrm{~cm}^{-2}\right)$. These results clearly show the importance of the pore distribution in carbon nanomaterials in DET-type bioelectrocatalysis.

\subsection{Effects of Surface Chemistry}

Carbon nanomaterials are frequently formed with hydrophobic and chemically inactivate surfaces, whereas functional groups, such as hydroxyl, carboxyl, and carbonyl, can be formed at the surfaces of carbon nanomaterials, depending on the preparation and treatment approaches. For example, carboxyl groups are frequently found in oxidized CNTs, which can be produced by treatment with acid or peroxides. By contrast, redox enzyme surfaces usually consist of polar amino acids, some of which can even be charged in a solution. Intricate interactions between carbon nanomaterials and redox enzymes have been proposed to play important roles in the orientation and interfacial electron transfer rate of redox enzymes [40]. For example, an improved electron transfer has been reported in BOD on UV-ozone treated carbon black [41] and carbon nanofiber [42] surfaces. UV-ozone treatment was proposed to produce hydrophobically and negatively oxygenated functional groups in carbon nanomaterials. In addition, the $\mathrm{O}_{2}$-reduction current produced from the DET-type bioelectrocatalyst of TrLac at the CNT decreases with increasing N dopant ratio [43]. Strong electrostatic interactions between N-doped CNTs, which have a positive surface potential, and laccase has been proposed to cause the denaturation of redox enzymes and/or decrease the DET reaction rate. Furthermore, the zeta potential (i.e., surface charge density) of graphene oxide has been reported to affect the enzyme adsorption, direct electron transfer, and catalytic current [44]. In a recent study, three types of carbon nanotubes with different lengths were utilized as platforms for the DET-type bioelectrocatalysis of three redox enzymes, viz. BOD from Myrothecium verrucaria (MvBOD), CueO from Escherichia coli, and $\mathrm{H}_{2}$ ase from Desulfovibrio vulgaris Miyazaki F (Dv $\mathrm{H}_{2}$ ase) [45]. As a result, diffusion-controlled $\mathrm{O}_{2}$ 
reduction reaction with catalytic current density of $\sim 8 \mathrm{~mA} \mathrm{~cm}^{-2}$ in an $\mathrm{O}_{2}$-saturated neutral buffer was realized by BOD in CNTs of a length of $1 \mu \mathrm{m}$, but the catalytic current densities decreased as the length of CNTs increased [45] (Figure 3). However, in the cases of CueO and $\mathrm{H}_{2}$ ase, the catalytic current $\left(\mathrm{O}_{2}\right.$ reduction for CueO and $\mathrm{H}_{2}$ oxidation for $\mathrm{DvH}_{2}$ ase $)$ increases as the length of CNTs increased. This tendency can be weakened by the addition of $\mathrm{Ca}\left(\mathrm{NO}_{3}\right)_{2}$ to the electrolyte. The CNT surface is negatively charged in neutral solutions owing to the dissociation of the carboxyl group on the CNT surface, and the number of carboxy groups increases with a decreasing CNT length. It was concluded through this research that the electrostatic interaction between the region close to the active site of the enzymes and CNTs is one of the most important factors controlling the enzyme adsorption for DET-type bioelectrocatalysis.
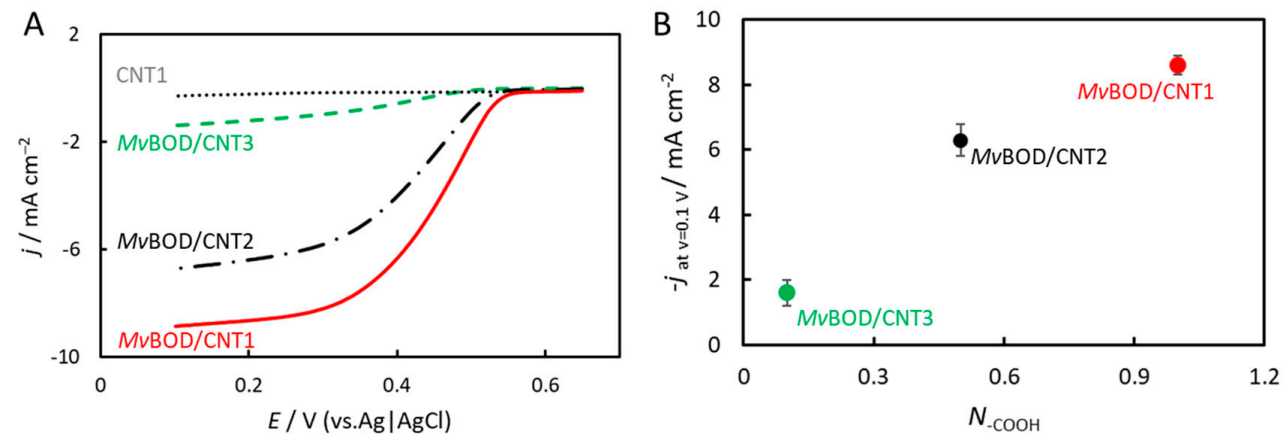

Figure 3. (A) Rotating disk linear scan voltammograms (LSVs) of $\mathrm{O}_{2}$ reduction for $\mathrm{MvBOD} / \mathrm{CNT1}$ (solid line), MvBOD/CNT2 (dashed-dotted line), and MvBOD/CNT3 (broken line). The dotted line represents an LSV on a CNT1 without enzyme. All measurements were carried out in $\mathrm{O}_{2}$-saturated phosphate buffer $\left(0.1 \mathrm{M}, \mathrm{pH} 7.0\right.$, and $\left.25^{\circ} \mathrm{C}\right)$ at $\omega=4000 \mathrm{rpm}$ and $v=5 \mathrm{mV} \mathrm{s}^{-1}$. (B) Relationships between the steady state current density and the relative amount of carboxy groups at different CNT surfaces $\left(N_{-} \mathrm{COOH}\right)$. Reprint from [45]. Copyright (2017), with permission from Elsevier.

\section{Oriented Immobilization of Redox Enzymes in Modified Carbon Nanomaterials}

Because the surface physiochemistry of carbon nanomaterials plays a key role in the orientation of redox enzymes, strategies for the rational surface modification of carbon nanomaterials to provide suitable platforms for DET-type bioelectrocatalysis of redox enzymes are highly expected. In general, functional groups at carbon nanomaterial surfaces can be introduced by different approaches, including diazonium electroreduction [46], amine electrooxidation [47], $\pi$-stacking [48], and in-situ chemical modification [49] (Figure 4). We do not discuss these approaches in detail herein, focusing instead on strategies to control the orientation of redox enzymes in modified carbon nanomaterials for enhanced DET-type bioelectrocatalysis.

$$
\text { A }
$$
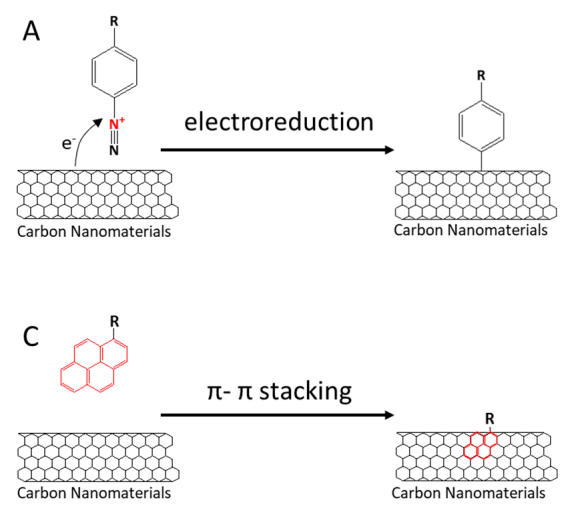
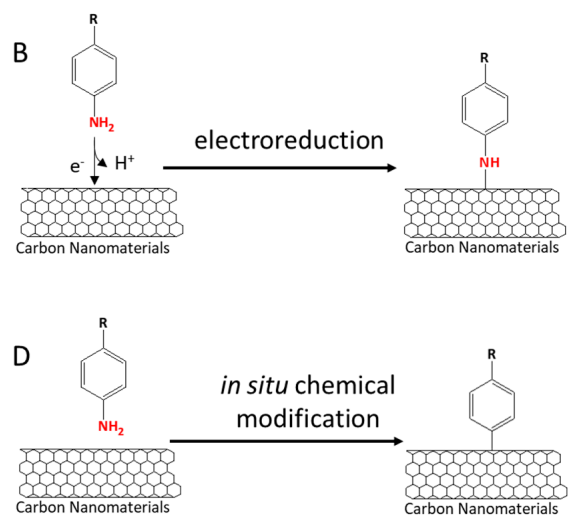

Figure 4. Typical strategies for surface modification of carbon nanomaterials. CNTs were utilized here as representatives of carbon nanomaterials. 


\subsection{Modification of Carbon Nanomaterials with Charged Compounds}

Electrostatic effects play major roles in enzyme-substrate interactions and in DET-type bioelectrocatalysis. For example, it has been found that the electrode potential may affect the adsorption and orientation, and thus, the performance of DET-type bioelectrocatalysis of redox enzymes [50]. In addition, improved $\mathrm{O}_{2}$-reduction reactions have been achieved through the adsorption of $\mathrm{MvBOD}$ on negatively charged surfaces, which were produced by the electrooxidation of 4-aminobenzoic acid at the KB [12,47,51], reduced graphene oxide [52], or MgO-templated mesoporous carbon [34] modified electrodes. Specially, the $\mathrm{O}_{2}$ reduction-current densities produced by $\mathrm{MvBOD}$ at 4-aminobenzoic acid functionalized $\mathrm{KB}$ modified electrodes is more than 2 times higher than that at pristine KB modified electrodes [12,47] (Figure 5A). The net charge of $\mathrm{MvBOD}$ is negative at $\mathrm{pH} 7$, whereas the surface close to the type I copper, the site that is believed to accept electrons from the electrode in the DET reaction case, is positive at $\mathrm{pH} 7$. The electrostatic interaction between the 4-aminobenzoic acid-functionalized carbon surface and the positively charged $\mathrm{T} 1$ site is proposed to provide an effective orientation for the DET-type bioelectrocatalysis of $M v B O D$ [47]. Such enhancement can also be found through the adsorption of $M v B O D$ at naphthoate-functionalized CNT-modified electrodes [53], which were prepared using the electrochemical reduction of 6-carboxynaphthalenediazonium or by the in-situ chemical modification of 6-amino-2-naphthoic acid onto CNTs. Similar phenomena have also been reported in Magnaporthe orizae $\mathrm{BOD}(\mathrm{MoBOD})$, which illustrated improved oxygen reduction reactions at 6-carboxynaphthalenediazonium functionalized CNTs [54]. In contrast to MvBOD and MoBOD, BOD from Bacillus pumilus (BpBOD) presents a negatively charged $\mathrm{T} 1$ site. As expected, the $\mathrm{O}_{2}$-reduction current produced by $\mathrm{B} p \mathrm{BOD}$ at a positively charged 1-pyrenemethylamine hydrochloride-functionalized CNT electrode is $\sim 0.4 \mathrm{~mA} \mathrm{~cm}^{-2}$, which is much higher than that at a pristine CNT electrode $\left(\sim 0.05 \mathrm{~mA} \mathrm{~cm}^{-2}\right)$ [55]. Similarly, CueO [56] and $\mathrm{DvH}_{2}$ ase [51], which have negatively charged active sites for interfacial electron transfer, show enhanced DET-type bioelectrocatalysis at a p-phenylenediamine-functionalized KB electrode. Consequently, improved DET-type bioelectrocatalysis based on an electrostatic interaction has been applied to the construction of a $\mathrm{H}_{2} / \operatorname{Air}\left(\mathrm{O}_{2}\right)$ enzymatic biological fuel cell, which consists of a $M v B O D$-adsorbed 4-aminobenzoic acid-modified $\mathrm{KB}$ biocathode and $\mathrm{Dv} \mathrm{H}_{2}$ ase adsorbed p-phenylenediamine-functionalized $\mathrm{KB}$ bioanode, with a high-power density of $6.1 \mathrm{~mW} \mathrm{~cm}^{-2}$ [51], which is the highest output of DET-type biological fuel cells reported thus far.

\subsection{Modification of Carbon Nanomaterials with Polycyclic Compounds}

Contrary to the charged surface of redox enzymes, the active site of redox enzymes is usually surrounded by polypeptides to form a substrate-binding "pocket" that is often non-charged and hydrophobic. Based on this knowledge, by modifying an electrode surface with polycyclic aromatic compounds, the hydrophobic interactions ( $\pi-\pi$ stacking) between the active center "pocket" of the enzyme and the modifier may induce a favorable orientation. Anthracene and its derivatives are the most common groups that are modified into carbon nanomaterials for the oriented immobilization of redox enzymes. The concept was first proposed by Armstrong and his coworkers, who reported an improved $\mathrm{O}_{2}$-reduction reaction by the adsorption of laccase at the anthracene-functionalized pyrolytic graphite "edge" electrode [57]. This approach has been further developed for the orientated-immobilization of laccase at CNTs functionalized with anthracene-2-carbonyl chloride [58] or 1-(2-anthraquinonylaminomethyl) pyrene [59]. For example, the optimized $\mathrm{O}_{2}$-reduction current density produced by TvLac at an anthracene-2-carbonyl chloride functionalized CNT electrode is $140 \mu \mathrm{A} \mathrm{cm}^{-2}$, while no obvious catalytic current can be observed by TvLac at a pristine CNT electrode [58]. In these studies, polycyclic anthracene groups tailored to carbon nanomaterials were expected to insert the hydrophobic substrate-binding "pocket" to control the orientation of redox enzymes for an efficient interfacial electron transfer. Interestingly, CNTs modified by 1-[bis(2-anthraquinonyl)aminomethyl] pyrene $\left(\mathrm{PyrAQ}_{2}\right)$ with two anthraquinone groups showed greater efficiency for improvement of DET-type bioelectrocatalysis of laccase than that modified by 1-(2-anthraquinonylaminomethyl) pyrene (PyrAQ) with only one anthraquinone group [60]. 
The $\mathrm{O}_{2}$-reduction current density produced by TvLac at $\mathrm{PyrAQ}_{2}$-functionalized CNT electrodes reached to $0.9 \mathrm{~mA} \mathrm{~cm}^{-2}$, which is much higher than that at PyrAQ-functionalized CNT electrodes $\left(0.35 \mathrm{~mA} \mathrm{~cm}^{-2}\right)$ [60]. The increased anthraquinone groups seem to increase the probability of laccases with a controlled orientation. In addition to anthracene, surfaces functionalized by pyrene [61] and adamantane [62] have been found to be efficient in controlling the orientation of Lac for the improvement of DET-type bioelectrocatalysis. (Figure 5B) Furthermore, such improved DET-type bioelectrocatalysis using a similar approach has also been reported when using FDH in anthracene-functionalized CNTs [63] and Desulfomicrobium baculatum $\mathrm{H}_{2}$ ase $\left(\mathrm{DbH}_{2}\right.$ ase) in anthraquinone- or adamantane-functionalized CNTs [64].

\subsection{Modification of Carbon Nanomaterials with Substrate Mimics}

Compared to nonspecific electrostatic and hydrophobic interactions, interactions between redox enzymes and their natural substrates are usually highly specific. A more effective approach is the direct functionalization of carbon nanomaterials with a natural substrate (or its analogues) of redox enzymes to control the orientation of the redox enzymes. A significant improvement in the $\mathrm{O}_{2}$-reduction current has been realized through the adsorption of $\mathrm{MvBOD}$ in bilirubin, the natural substrate of $\mathrm{MvBOD}$, which is a functionalized KB electrode [65]. (Figure 5C) A computational study that combines the density functional theory with docking simulations showed that the modification of the electrode surface with bilirubin provides an optimal orientation of BOD toward the support and that bilirubin facilitates the interfacial electron transfer by decreasing the distance between the electrode surface and the T1 Cu atom [66]. Similar improvements in DET-type bioelectrocatalysis can be realized through the adsorption of $\mathrm{MvBOD}$ at 2,5-dimethyl-1-phenyl-1H-pyrrole-3-carbaldehyde [67], syringaldazine [68], or protoporphyrin [69], analogues of bilirubin, and functionalized CNT electrodes. Syringaldazine-functionalized CNTs were also shown to be positively effective in improving the interfacial electron transfer of laccase [68]. Moreover, an improved DET-type bioelectrocatalysis of FDH at a methoxy-functionalized electrode surface [70] based on the specific interactions between FDH and methoxy substituents [8] has been reported. The fructose oxidation current produced by $\mathrm{FDH}$ at 2,4-dimethoxyaniline-functionalized $\mathrm{KB}$ electrodes reached to $23 \pm 2 \mathrm{~mA} \mathrm{~cm}^{-2}$, which is the largest measured to date. A recent study proposed that 4-mercaptopyridine functionalized gold nanoparticle-embedded KB can act as a favorable platform for DET-type bioelectrocatalysis of FoDH [71], probably owing to the attractive interactions between the pyridine moiety and the FeS site of FoDH. These results suggest that site-specific interactions are also effective in inducing a suitable orientation of redox enzymes for DET-type bioelectrocatalysis.

\subsection{Oriented Immobilization of Engineered Enzymes in Functionalized Carbon Nanomaterials}

The conventional method for oriented immobilization of redox enzymes is dependent on the natural properties of redox enzymes. Engineered redox enzymes with specific residues for oriented immobilization in modified carbon nanomaterials have recently been reported. Bartlett et al. constructed a site-specific variant of MoBOD S362C, in which Ser362 at the MoBOD surface close to the TI Cu was replaced by a Cys residue [72]. The distance between the T1 site and Ser362 is $\sim 1.33 \mathrm{~nm}$. A thiol-maleimide click reaction between the S362CMoBOD variant and maleimide-functionalized MWCNT was employed to construct a stable bioelectrode. A clear DET-type bioelectrocatalytic $\mathrm{O}_{2}$ reduction wave with a higher current and more sigmoidal shape was obtained in a S362CMoBOD-modified electrode than that in a native MoBOD-modified electrode. Such improvements in DET-type bioelectrocatalytic performance can be explained by the oriented immobilization of the enzyme with a short distance between the active site and the electrodes. A site-specific surface modification of a fungal Lac with a single covalently bound pyrene group close to the T1 site showed improved DET-type bioelectrocatalysis in the CNTs [73]. (Figure 5D) The site-specific modified pyrene was attached to the CNT through a $\pi-\pi$ stacking interaction to control the orientation of Lac with the $\mathrm{T} 1$ site face to the $\mathrm{CNT}$. As a result, a maximum $\mathrm{O}_{2}$-reduction current density produced by site-specific pyrene-modified Lac at a CNT electrode is $1.15 \mathrm{~mA} \mathrm{~cm}^{-2}$, which is four times higher than that 
produced by native Lac at a CNT electrode $\left(0.27 \mathrm{~mA} \mathrm{~cm}^{-2}\right)$. A further improved maximum $\mathrm{O}_{2}$-reduction current density of $2.75 \mathrm{~mA} \mathrm{~cm}^{-2}$ was realized by immobilizing site-specific pyrene-modified Lac at $\beta$-cyclodextrin-modified gold nanoparticles( $\beta$-CD-AuNPs)-functionalized CNT [73]. The $\beta$-CD-AuNPs offer host-guest interactions between pyrene groups and $\beta$-CD moieties on the AuNPs surface to increase the number of effectively wired enzymes. A recent study on the oriented immobilization of site-specific alkylated Lac in azido-modified CNTs through copper-catalyzed click reactions was reported by the same group [74]. Interestingly, it has been found that the variant with an alkyne group in the position close to the $\mathrm{T} 2 / \mathrm{T} 3$ site showed a higher $\mathrm{O}_{2}$-reaction current $\left(\sim 3 \mathrm{~mA} \mathrm{~cm}^{-2)}\right.$ than that with an alkyne group close to the $\mathrm{T} 1$ site $\left(\sim 1.8 \mathrm{~mA} \mathrm{~cm}^{-2}\right)$. Although several studies have reported a direct electron transfer from the electrode to the T2/T3 cluster of Lac in gold electrodes [75], more experimental evidence is needed to support this finding.
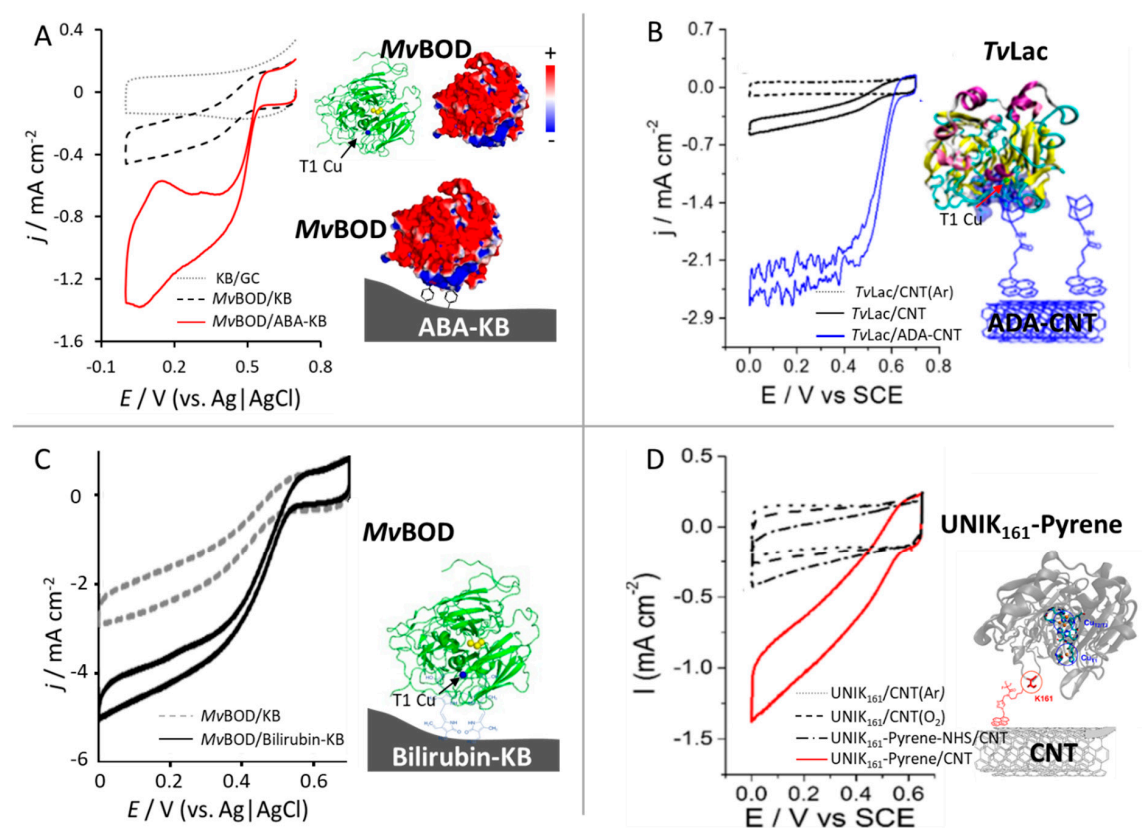

Figure 5. Examples of oriented immobilization of redox enzymes in modified carbon nanomaterials. (A) Cyclic voltammograms (CVs) of MvBOD adsorbed in pristine $\mathrm{KB}$ (dashed line) and 4-aminobenzoic acid-functionalized KB (solid line) electrodes in an air-saturated phosphate buffer (0.1 M, pH 7.0) with a rotating rate of $2000 \mathrm{rpm}$. The dotted line shows the cyclic voltammogram of a bare KB electrode without MvBOD. Reprinted from [47] Copyright (2016) with permission from Elsevier. (B) CVs of TvLac adsorbed in pristine CNTs (black solid line) and 1-pyrenebutyric acid adamantyl amide-functionalized CNTs (ADA-CNT, blue solid line) in a stirred oxygen-saturated McIlvaine buffer (pH 5). The dotted line shows the cyclic voltammogram of the TvLac adsorbed CNT electrode in an argon-saturated buffer. Reprinted from [62] Copyright (2016) with permission from American Chemical Society. (C) CVs of $\mathrm{M} v \mathrm{BOD}$ adsorbed in pristine KB (dashed line) and bilirubin functionalized KB (solid lines) electrodes in an $\mathrm{O}_{2}$-saturated phosphate buffer $(0.1 \mathrm{M}, \mathrm{pH} 7)$ with a rotating rate of $4000 \mathrm{rpm}$. The inset shows the structure of bilirubin. Reprinted from [65] Copyright (2014) with permission from Royal Society of Chemistry. (D) CVs of the bare $\mathrm{UNIK}_{161}$ (dotted line), $\mathrm{UNIK}_{161}-\mathrm{NHS}$-pyrene (dashed-dotted line), and $\mathrm{UNIK}_{161}$-pyrene (solid line) adsorbed in CNT electrodes in $\mathrm{O}_{2}$-saturated $0.1 \mathrm{M}$ phosphate buffer ( $\mathrm{pH}$ 5.0). The dotted line shows bare UNIK161 adsorbed CNT electrodes in an argon-saturated buffer. UNIK $_{161}$ is a variant of the LAC3 enzyme (GENEBANK AAR00925.1) containing lysine, methionine, and histidine residues replacing arginine R161 (R > K161) and lysines K40 (K > M40) and K71 (K > H71) in the native sequence, respectively; in addition, UNIK161-NHS-pyrene indicates that the enzyme was modified with pyrene-NHS, which was randomly attached to UNIK 161 through an activated ester coupling. UNIK 161 -pyrene is produced through the highly selective modifications of K161 with pyrene Rreprinted from [73] Copyright (2016) with permission from American Chemical Society. 


\section{Techniques to Probe the Redox Enzymes in Carbon Nanomaterials}

Although electrochemical investigations (e.g., rotating disk electrodes) coupled with computational simulations [66,76] and a theoretical analysis of current-potential curves $[77,78]$ for an investigation into DET-type bioelectrocatalysis have been well studied during the past 10 years, techniques to directly probe the behavior of redox enzymes in carbon nanomaterials are still highly desired [79]. Several techniques, particularly a quartz crystal microbalance (QCM) and infrared (IR) spectroscopy, used to analyze the enzyme adsorption, conformation, and orientation of redox enzymes in carbon nanomaterials have been proposed and developed during the past decades.

\subsection{Quartz Crystal Microbalance}

A quartz crystal microbalance (QCM) is a powerful technique commonly used to measure the adsorption of redox enzymes onto an electrode surface. In general, a QCM instrument operates by measuring the resonance frequency of a piezoelectric quartz chip. According to the Sauerbrey equation [80], the frequency of a piezoelectric quartz chip is typically proportional to the mass on the electrode (assuming a rigid thin film). By coating the piezoelectric quartz chip with carbon nanomaterials, the adsorption behaviors of redox enzymes at the corresponding surfaces can be obtained. Furthermore, considering the large size and structural flexibility of redox enzymes, QCM with dissipation (QCM-D) monitoring to further understand the rigidity of enzyme binding, desorption, reorientation, and conformational changes has been proposed [81]. For example, much greater decreases in frequency and increases in the dissipation factor have been found for the adsorption of TvLac onto adamantane-functionalized CNT electrodes than onto pristine CNT electrodes [62]. The results indicate higher enzyme loading and stable immobilization of laccase in adamantane-functionalized CNTs than in pristine CNT electrodes. A similar study reported by the same group also showed increased frequency decreases and dissipation factor increases for the adsorption of $\mathrm{DbH}_{2}$ ase onto adamantane- and anthraquinone-functionalized CNT electrodes [63]. In combination with electrochemical measurements, these studies have concluded that the functionalization of CNTs with adamantane or anthraquinone groups increase the effective adsorption of TvLac and $\mathrm{DbH}_{2}$ ase for DET-type bioelectrocatalysis owing to the hydrophobic interaction between the active site pocket of redox enzymes and a functionalized polycyclic modifier. A recent study revealed that upon adsorption of TrLac onto naphthalene-functionalized CNTs, dissipation increased and resonance frequency decreased rapidly, followed by slow dissipation decrease [82].(Figure 6A) The first rapid dissipation increase and resonance frequency decrease are typical behaviors of protein adsorption, whereas the subsequent slow decrease in dissipation was proposed to be caused by the rearrangement of adsorbed TrLac, which is important for an electric connection of TrLac to the naphthalene-functionalized CNTs by cross-comparing the results of an open circuit potential monitoring and dissipation response.

\subsection{Infrared Spectroscopy}

Infrared (IR) spectroscopy is a well-established experimental technique for analyzing the secondary structures of proteins [83]. IR vibrational spectra contain a wealth of information about the structure and environment of amino acid side chains, as well as protein conformation and the polypeptide backbone. For in-situ investigation of the redox enzymes at the electrode surfaces, reflection-based methods, particularly attenuated total-reflectance infrared (ATR-IR) spectroscopy, are the most commonly used. The strongest features in the ATR-IR spectra of enzymes are typically amide bands (e.g., amide I at $\sim 1650 \mathrm{~cm}^{-1}$ and amide II at $\sim 1550 \mathrm{~cm}^{-1}$ ) that arise from the amide bonds in the polypeptide backbone and sensitively encode the secondary structure of the enzyme. Mao et al. developed an ATR-IR spectroscopy-based method for investigating the effects of organic solvents on the immobilization of TvLac on CNTs [84]. Six typical secondary structures in TvLac with and without ethanol treatment adsorbed on CNTs were resolved and compared. It has been found that the content of high-frequency (HF) $\beta$-sheets, which corresponds to the flexible $\beta$-extend, dropped 
to just above zero after immobilization in the CNTs, while it increased by $\sim 200 \%$ in ethanol-treated TvLac. In addition, a stronger amide II peak was obtained with ethanol-treated TvLac-CNT electrodes, showing an increased amount of detectable $\mathrm{N}-\mathrm{H}$ in-plane bending events. The ratio of the amide I/II peak intensity was reduced at the ethanol-treated TvLac-CNT electrode, compared to that at the non-treated TvLac-CNT electrodes, indicating a significant orientation change of the adsorbed TvLac. With improved $\mathrm{O}_{2}$-reduction currents, ethanol-treated TvLac facilitating a favorable "end-on" orientation at the CNT surfaces for fast direct electron transfer was proposed. (Figure 6B) Based on a similar ATR-IR technique, the orientations of the small Lac in carbon nanomaterials were investigated [85]. Consequently, the effects of the surface curvature of carbon nanomaterials on the orientation of adsorbed small Lac in the view of DET-type bioelectrocatalysis was proposed.
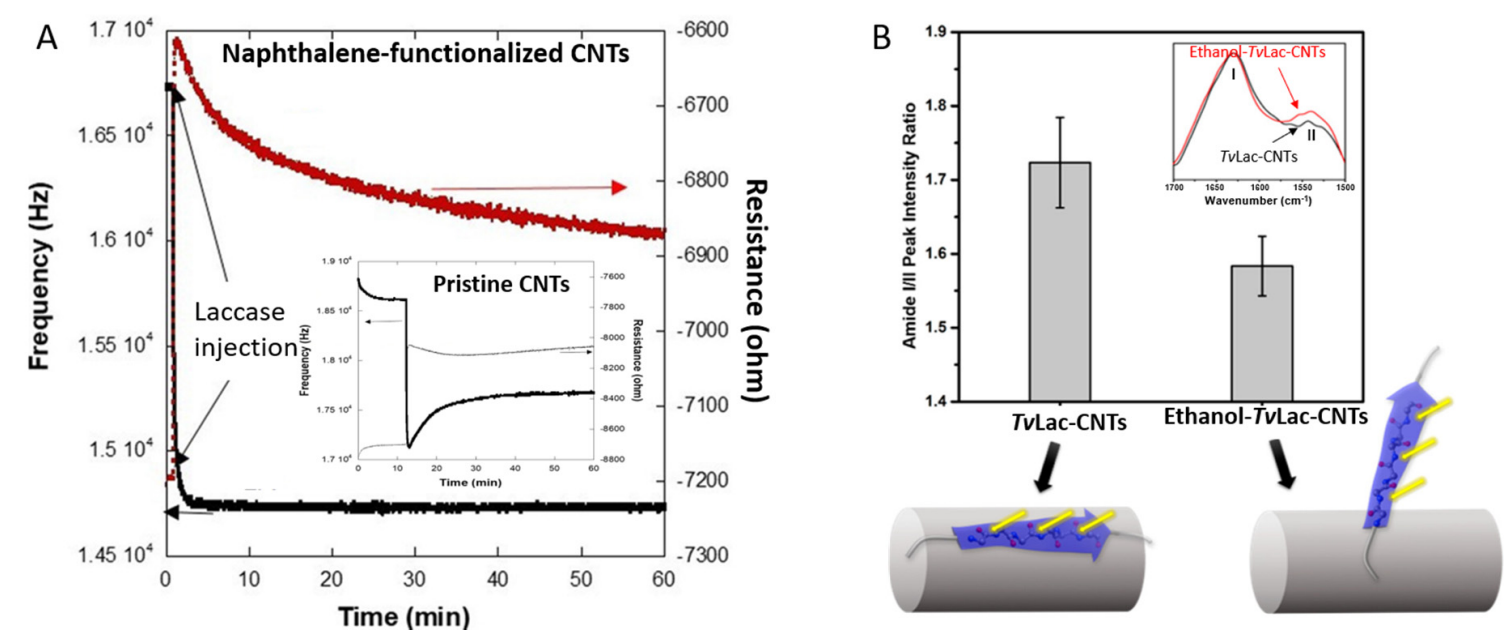

Figure 6. (A) QCM-D response of naphthalene-functionalized CNTs modified gold surface before and after TrLac injection. The inset shows the QCM-D response of pristine CNTs modified gold surface before and after TrLac injection. Reprinted from [82] Copyright (2020) with permission from Elsevier. (B) Two orientations of $\beta$-strand at the surface of CNTs predicted from the Amide I/II peak intensity ratios. Inset: Amide I and II band regions on difference IR spectra (corrected by a linear baseline between 1700 and $1500 \mathrm{~cm}^{-1}$ ) of the untreated TvLac-CNT film (black line) and Ethanol-treated TvLac-CNT film (red line). Yellow arrows represent incident light. Amide bonds (ball and sticks) are in the plane of $\beta$-strand. Reprinted from [85] Copyright (2017) with permission from American Chemical Society.

\section{Conclusions}

DET-type bioelectrocatalysis is an ideal system that employs redox enzymes as biocatalysts for energy conversion under extremely mild conditions. The properties of redox enzymes lead to reactions with high specificity and high catalytic efficiency, which are suitable for various electrochemical devices, including biosensors, biofuel cells, and bioreactors. The major challenges for DET bioelectrocatalysis are the interfacial electron transfer between redox enzymes and electrodes. Carbon nanomaterials with high conductivity, large specific surface areas, and three-dimensional nanostructures have been widely utilized for the construction of bioelectrodes with the capability of DET.

In this review, we focused on the rational surface modification of carbon nanomaterials for improving DET-type bioelectrocatalysis based on an understanding of the effects of carbon nanomaterials on the interfacial electron transfer between redox enzymes and electrodes. Although a large specific surface area is important for increasing the enzyme loading, a suitable pore size distribution and specific surface chemistry of carbon nanomaterials have recently been proposed to play important roles in the promotion of interfacial electron transfer between redox enzymes and electrodes. Carbon nanomaterials, with hierarchical porosity that balance the enzyme adsorption, electron transfer, and mass transfer, are expected to be suitable for high-performance DET-type bioelectrocatalysis. By contrast, intricate interactions between redox enzymes and carbon nanomaterials play an important 
role in the orientation of redox enzymes. From this perspective, rational surface modification based on an understanding of the interaction between enzymes and the specific modifier to control the orientation of the redox enzymes for improved DET-type bioelectrocatalysis has been developed during the past decades. Typically, charged compounds, polycyclic aromatics, and substrate mimics have usually been utilized for the construction of functionalized carbon nanomaterials for controlling the orientation of redox enzymes. Unlike the random surface properties of native enzymes, recently developed engineered enzymes with specific sites that can be immobilized onto modified carbon nanomaterials with controlled orientations have also attracted increased attention. To further understand the situation of redox enzymes in carbon nanomaterials, various techniques other than the use of electrochemical methods alone are highly desired. In particular, QCM-D and ATR-IR spectroscopy have been utilized to investigate the adsorption, conformational change, and orientation distribution of redox enzymes in carbon nanomaterials.

Although significant progress has been made in the past decades, several important issues regarding the DET-type bioelectrocatalysis are still waiting to be tackled. Firstly, detail mechanism of DET reaction is still instinct. Advanced technology, for example coupling-technique as well as single molecule analysis, is desired to deeply understand the process of electron transfer between a redox enzyme and electrode surfaces. Further development in theoretical discussion on this issue is also expected. Secondly, redox enzyme that capable of DET-type bioelectrocatalysis is limited in number. Native redox enzymes have usually large and sophisticated three-dimensional molecular structures. Besides to electrode surface modification discussed in this review, protein engineering to reform redox enzymes, for example shortening the distance between active site and enzyme surfaces by elimination of the domains that are not related to the electron transfer, is proposed to improve the performance of DET-type bioelectrocatalysis effectively. Thirdly, stability is continued to be an important issue in DET-type bioelectrocatalysis for practical applications. Strategies including optimization of enzyme immobilization approaches, tuning enzyme properties and using suitable electrode materials have been proposed recently to improve the stability and increase the lifetime of redox enzymes at electrode surfaces for rapid interfacial electron transfer.

Author Contributions: H.X.: Original manuscript preparation and revision; J.Z.: Revision and discussion. All authors have read and agreed to the published version of the manuscript.

Funding: This research is partially supported by Guangdong Basic and Applied Basic Research Foundation (No. 2019A1515111183) and President Foundation of Institute of Fruit Tree Research, Guangdong Academy of Agricultural Science (No. 202005).

Conflicts of Interest: The authors declare no conflict of interest.

\section{References}

1. Xiao, X.; Xia, H.Q.; Wu, R.; Bai, L.; Yan, L.; Magner, E.; Cosnier, S.; Lojou, E.; Zhu, Z.; Liu, A. Tackling the Challenges of Enzymatic (Bio)Fuel Cells. Chem. Rev. 2019, 119, 9509. [CrossRef]

2. Adachi, T.; Kitazumi, Y.; Shirai, O.; Kano, K. Development Perspective of Bioelectrocatalysis-Based Biosensors. Sensors 2020, 20, 4826. [CrossRef]

3. Wu, R.; Ma, C.; Zhu, Z. Enzymatic Electrosynthesis as an Emerging Electrochemical Synthesis Platform. Curr. Opin. Electrochem. 2020, 19, 1-7. [CrossRef]

4. Karimian, N.; Hashemi, P.; Khanmohammadi, A.; Afkhami, A.; Bagheri, H. The Principles and Recent Applications of Bioelectrocatalysis. Anal. Bioanal. Chem. Res. 2020, 7, 281.

5. Kano, K.; Ikeda, T. Fundamentals and Practices of Mediated Bioelectrocatalysis. Anal. Sci. 2000, 16, 1013. [CrossRef]

6. Karyakin, A.A. Principles of Direct (Mediator Free) Bioelectrocatalysis. Bioelectrochemistry 2012, 88, 70-75. [CrossRef]

7. Sensi, M.; del Barrio, M.; Baffert, C.; Fourmond, V.; Léger, C. New Perspectives in Hydrogenase Direct Electrochemistry. Curr. Opin. Electrochem. 2017, 5, 135-145. [CrossRef] 
8. Kawai, S.; Yakushi, T.; Matsushita, K.; Kitazumi, Y.; Shirai, O.; Kano, K. The Electron Transfer Pathway in Direct Electrochemical Communication of Fructose Dehydrogenase with Electrodes. Electrochem. Commun. 2014, 38, 28-31. [CrossRef]

9. Kamitaka, Y.; Tsujimura, S.; Ikeda, T.; Kano, K. Electrochemical Quartz Crystal Microbalance Study of Direct Bioelectrocatalytic Reduction of Bilirubin Oxidase. Electrochemistry 2006, 74, 642-644. [CrossRef]

10. Bagdžiūnas, G.; Ramanavičius, A. Towards Direct Enzyme Wiring: A Theoretical Investigation of Charge Carrier Transfer Mechanisms between Glucose Oxidase and Organic Semiconductors. Phys. Chem. Chem. Phys. 2019, 21, 2968. [CrossRef]

11. Giese, B.; Graber, M.; Cordes, M. Electron Transfer in Peptides and Proteins. Curr. Opin. Chem. Biol. 2008, $12,755$. [CrossRef]

12. Sakai, K.; Xia, H.-Q.; Kitazumi, Y.; Shirai, O.; Kano, K. Assembly of Direct-Electron-Transfer-Type Bioelectrodes with High Performance. Electrochim. Acta 2018, 271, 305-311. [CrossRef]

13. Adachi, T.; Kitazumi, Y.; Shirai, O.; Kano, K. Direct Electron Transfer-Type Bioelectrocatalysis of Redox Enzymes at Nanostructured Electrodes. Catalysts 2020, 10, 236. [CrossRef]

14. Marcus, R.A. Chemical and Electrochemical Electron-Transfer Theory. Annu. Rev. Phys. Chem. 1964, 15, 155. [CrossRef]

15. Marcus, R.A. Electron Transfer Reactions in Chemistry: Theory and Experiment (Nobel Lecture). Angew. Chem. Int. Ed. 1993, 32, 1111. [CrossRef]

16. Sugimoto, Y.; So, K.; Xia, H.Q.; Kano, K. Encyclopedia of Interfacial Chemistry: Surface Science and Electrochemistry; Wandelt, K., Ed.; Elsevier: Amsterdam, The Netherlands, 2018; Volume 7.1.

17. Hitaishi, V.; Clement, R.; Bourassin, N.; Baaden, M.; de Poulpiquet, A.; Sacquin-Mora, S.; Ciaccafava, A.; Lojou, E. Controlling Redox Enzyme Orientation at Planar Electrodes. Catalysts 2018, 8, 192. [CrossRef]

18. Li, N.; Wang, J.; Li, M. Electrochemistry at Carbon Nanotube Electrodes. Rev. Anal. Chem. 2003, 22, 19. [CrossRef]

19. Gong, K.; Yan, Y.; Zhang, M.; Su, L.; Xiong, S.; Mao, L. Electrochemistry and Electroanalytical Application of Carbon Nanotubes: A Review. Anal. Sci. 2005, 21, 1383. [CrossRef]

20. Pumera, M. Graphene-based Nanomaterials and Their Electrochemistry. Chem. Soc. Rev. 2010, $39,4146$. [CrossRef]

21. Lawrence, K.; Baker, C.L.; James, T.D.; Bull, S.D.; Lawrence, R.; Mitchels, J.M.; Opallo, M.; Arotiba, O.A.; Ozoemena, K.I.; Marken, F. Functionalized Carbon Nanoparticles, Blacks and Soots as Electron-Transfer Building Blocks and Conduits. Chem. Asian J. 2014, 9, 1226. [CrossRef]

22. Flexer, V.; Durand, F.; Tsujimura, S.; Mano, N. Efficient Direct Electron Transfer of PQQ-Glucose Dehydrogenase on Carbon Cryogel Electrodes at Neutral pH. Anal. Chem. 2011, 83, 5721. [CrossRef]

23. Kamitaka, Y.; Tsujimura, S.; Kano, K. High Current Density Bioelectrolysis of D-Fructose at Fructose Dehydrogenase-Adsorbed and Ketjen Black-Modified Electrodes without a Mediator. Chem. Lett. 2007, 36, 218. [CrossRef]

24. Tasca, F.; Zafar, M.N.; Harreither, W.; Nöll, G.; Ludwig, R.; Gorton, L. A Third Generation Glucose Biosensor Based on Cellobiose Dehydrogenase from Corynascus thermophilus and Single-Walled Carbon Nanotubes. Analyst 2011, 136, 2033. [CrossRef] [PubMed]

25. Sakai, K.; Sugimoto, Y.; Kitazumi, Y.; Shirai, O.; Takagi, K.; Kano, K. Direct Electron Transfer-Type Bioelectrocatalytic Interconversion of Carbon Dioxide/Formate and NAD ${ }^{+} / \mathrm{NADH}$ Redox Couples with Tungsten-Containing Formate Dehydrogenase. Electrochim. Acta 2017, 228, 537-544. [CrossRef]

26. Tsujimura, S.; Kamitaka, Y.; Kano, K. Diffusion-Controlled Oxygen Reduction on Multi-Copper Oxidase-Adsorbed Carbon Aerogel Electrodes without Mediator. Fuel Cells 2007, 7, 463-469. [CrossRef]

27. Tsujimura, S.; Miura, Y.; Kano, K. CueO-Immobilized Porous Carbon Electrode Exhibiting Improved Performance of Electrochemical Reduction of Dioxygen to Water. Electrochim. Acta 2008, 53, 5716. [CrossRef]

28. Xia, H.Q.; Kitazumi, Y.; Shirai, O.; Kano, K. Direct Electron Transfer-Type Bioelectrocatalysis of Peroxidase at Mesoporous Carbon Electrodes and Its Application for Glucose Determination Based on Bienzyme System. Anal. Sci. 2017, 33, 839-844. [CrossRef] 
29. Yin, Z.; Ji, Z.; Zhang, W.; Taylor, E.W.; Zeng, X.; Wei, J. The Glucose Effect on Direct Electrochemistry and Electron Transfer Reaction of Glucose Oxidase Entrapped in a Carbon Nanotube-Polymer Matrix. ChemistrySelect 2020, 5, 12224. [CrossRef]

30. Wilson, G.S. Native Glucose Oxidase Does Not Undergo Direct Electron Transfer. Biosens. Bioelectron. 2016, 82, vii-viii. [CrossRef]

31. Bartlett, P.N.; Al-Lolage, F.A. There Is No Evidence to Support Literature Claims of Direct Electron Transfer (DET) for Native Glucose Oxidase (GOx) at Carbon Nanotubes or Graphene. J. Electroanal. Chem. 2018, 819, 26-37. [CrossRef]

32. Tsujimura, S.; Nishina, A.; Hamano, Y.; Kano, K.; Shiraishi, S. Electrochemical Reaction of Fructose Dehydrogenase on Carbon Cryogel Electrodes with Controlled Pore Sizes. Electrochem. Commun. 2010, 12, 446-449. [CrossRef]

33. Funabashi, H.; Murata, K.; Tsujimura, S. Effect of Pore Size of MgO-Templated Carbon on the Direct Electrochemistry of D-Fructose Dehydrogenase. Electrochemistry 2015, 83, 372-375. [CrossRef]

34. Tsujimura, S.; Oyama, M.; Funabashi, H.; Ishii, S. Effects of Pore Size and Surface Properties of MgO-Templated Carbon on the Performance of Bilirubin Oxidase-Modified Oxygen Reduction Reaction Cathode. Electrochim. Acta 2019, 322, 134744. [CrossRef]

35. Mazurenko, I.; Clément, R.; Byrne-Kodjabachian, D.; de Poulpiquet, A.; Tsujimura, S.; Lojou, E. Pore Size Effect of MgO-Templated Carbon on Enzymatic $\mathrm{H}_{2}$ Oxidation by the Hyperthermophilic Hydrogenase from Aquifex aeolicus. J. Electroanal. Chem. 2018, 812, 221-226. [CrossRef]

36. Sugimoto, Y.; Kitazumi, Y.; Shirai, O.; Kano, K. Effects of Mesoporous Structures on Direct Electron Transfer-Type Bioelectrocatalysis: Facts and Simulation on a Three-Dimensional Model of Random Orientation of Enzymes. Electrochemistry 2017, 85, 82-87. [CrossRef]

37. Sugimoto, Y.; Takeuchi, R.; Kitazumi, Y.; Shirai, O.; Kano, K. Significance of Mesoporous Electrodes for Noncatalytic Faradaic Process of Randomly Oriented Redox Proteins. J. Phys. Chem. C 2016, 120, 26270. [CrossRef]

38. Wanibuchi, M.; Takahashi, Y.; Kitazumi, Y.; Shirai, O.; Kano, K. Significance of Nano-Structures of Carbon Materials for Direct-Electron-Transfer-Type Bioelectrocatalysis of Bilirubin Oxidase. Electrochemistry 2020, 88, 374. [CrossRef]

39. Funabashi, H.; Takeuchi, S.; Tsujimura, S. Hierarchical Meso/Macro-Porous Carbon Fabricated from Dual $\mathrm{MgO}$ Templates for Direct Electron Transfer Enzymatic Electrodes. Sci. Rep. 2017, 7, 45147. [CrossRef]

40. Hitaishi, V.P.; Clément, R.; Quattrocchi, L.; Parent, P.; Duché, D.; Zuily, L.; Ilbert, M.; Lojou, E.; Mazurenko, I. IInterplay between Orientation at Electrodes and Copper Activation of Thermus thermophilus Laccase for $\mathrm{O}_{2}$ Reduction. J. Am. Chem. Soc. 2020, 142, 1394. [CrossRef]

41. Tominaga, M.; Otani, M.; Kishikawa, M.; Taniguchi, I. UV-Ozone Treatments Improved Carbon Black Surface for Direct Electron-Transfer Reactions with Bilirubin Oxidase under Aerobic Conditions. Chem. Lett. 2006, 35, 1174. [CrossRef]

42. Xue, Q.; Kato, D.; Kamata, T.; Guo, Q.; You, T.; Niwa, O. Improved Direct Electrochemistry for Proteins Adsorbed on a UV/Ozone-Treated Carbon Nanofiber Electrode. Anal. Sci. 2013, 29, 611-618. [CrossRef] [PubMed]

43. Tominaga, M.; Togami, M.; Tsushida, M.; Kawai, D. Effect of N-Doping of Single-Walled Carbon Nanotubes on Bioelectrocatalysis of Laccase. Anal. Chem. 2014, 86, 5053. [CrossRef]

44. Filip, J.; Andicsová-Eckstein, A.; Vikartovská, A.; Tkac, J. Immobilization of Bilirubin Oxidase on Graphene Oxide Flakes with Different Negative Charge Density for Oxygen Reduction. The Effect of GO Charge Density on Enzyme Coverage, Electron Transfer Rate and Current Density. Biosens. Bioelectron. 2017, 89, 384-389. [CrossRef] [PubMed]

45. Xia, H.Q.; Kitazumi, Y.; Shirai, O.; Ozawa, H.; Onizuka, M.; Komukai, T.; Kano, K. Factors Affecting the Interaction between Carbon Nanotubes and Redox Enzymes in Direct Electron Transfer-Type Bioelectrocatalysis. Bioelectrochemistry 2017, 118, 70-74. [CrossRef] [PubMed]

46. Mohamed, A.A.; Salmi, Z.; Dahoumane, S.A.; Mekki, A.; Carbonnier, B.; Chehimi, M.M. Functionalization of Nanomaterials with Aryldiazonium Salts. Adv. Colloid Interface Sci. 2015, 225, 16-36. [CrossRef] [PubMed] 
47. Xia, H.-Q.; Kitazumi, Y.; Shirai, O.; Kano, K. Enhanced Direct Electron Transfer-Type Bioelectrocatalysis of Bilirubin Oxidase on Negatively Charged Aromatic Compound-Modified Carbon Electrode. J. Electroanal. Chem. 2016, 763, 104-109. [CrossRef]

48. Tournus, F.; Latil, S.; Heggie, M.I.; Charlier, J.-C. $\pi$-Stacking Interaction between Carbon Nanotubes and Organic Molecules. Phys. Rev. B 2005, 72, 075431. [CrossRef]

49. Lalaoui, N.; Le Goff, A.; Holzinger, M.; Mermoux, M.; Cosnier, S. Wiring Laccase on Covalently Modified Graphene: Carbon Nanotube Assemblies for the Direct Bio-Electrocatalytic Reduction of Oxygen. Chemistry 2015, 21, 3198. [CrossRef]

50. Hoshikawa, Y.; Castro-Muñiz, A.; Tawata, H.; Nozaki, K.; Yamane, S.; Itoh, T.; Kyotani, T. Orientation Control of Trametes Laccases on a Carbon Electrode Surface to Understand the Orientation Effect on the Electrocatalytic Activity. Bioconjug. Chem. 2018, 29, 2927. [CrossRef]

51. Xia, H.-Q.; So, K.; Kitazumi, Y.; Shirai, O.; Nishikawa, K.; Higuchi, Y.; Kano, K. Dual Gas-Diffusion Membraneand Mediatorless Dihydrogen/Air-Breathing Biofuel Cell Operating at Room Temperature. J. Power Sources 2016, 335, 105-112. [CrossRef]

52. Tang, J.; Yan, X.; Huang, W.; Engelbrekt, C.; Duus, J.Ø.; Ulstrup, J.; XIao, X.; Zhang, J. Bilirubin Oxidase Oriented on Novel Type Three-Dimensional Biocathodes with Reduced Graphene Aggregation for Biocathode. Biosens. Bioelectron. 2020, 167, 112500. [CrossRef] [PubMed]

53. Lalaoui, N.; Holzinger, M.; Le Goff, A.; Cosnier, S. Diazonium Functionalisation of Carbon Nanotubes for Specific Orientation of Multicopper Oxidases: Controlling Electron Entry Points and Oxygen Diffusion to the Enzyme. Chemistry 2016, 22, 10494. [CrossRef] [PubMed]

54. Gentil, S.; Carrière, M.; Cosnier, S.; Gounel, S.; Mano, N.; Le Goff, A. Direct Electrochemistry of Bilirubin Oxidase from Magnaporthe Orizae on Covalently-Functionalized MWCNT for the Design of High-Performance Oxygen-Reducing Biocathodes. Chemistry 2018, 24, 8404. [CrossRef] [PubMed]

55. Mazurenko, I.; Monsalve, K.; Rouhana, J.; Parent, P.; Laffon, C.; Goff, A.L.; Szunerits, S.; Boukherroub, R.; Giudici-Orticoni, M.T.; Mano, N.; et al. How the Intricate Interactions between Carbon Nanotubes and Two Bilirubin Oxidases Control Direct and Mediated $\mathrm{O}_{2}$ Reduction. ACS Appl. Mater. Interfaces 2016, 8, 23074. [CrossRef] [PubMed]

56. Adachi, T.; Kitazumi, Y.; Shirai, O.; Kawano, T.; Kataoka, K.; Kano, K. Effects of Elimination of $\alpha$ Helix Regions on Direct Electron Transfer-Type Bioelectrocatalytic Properties of Copper Efflux Oxidase. Electrochemistry 2020, 88, 185. [CrossRef]

57. Blanford, C.F.; Heath, R.S.; Armstrong, F.A.; Stable, A. Electrode for High-Potential, Electrocatalytic $\mathrm{O}_{2}$ Reduction Based on Rational Attachment of a Blue Copper Oxidase to a Graphite Surface. Chem. Commun. 2007, 17, 1710. [CrossRef]

58. Meredith, M.T.; Minson, M.; Hickey, D.; Artyushkova, K.; Glatzhofer, D.T.; Minteer, S.D. Anthracene-Modified Multi-Walled Carbon Nanotubes as Direct Electron Transfer Scaffolds for Enzymatic Oxygen Reduction. ACS Catal. 2011, 1, 1683. [CrossRef]

59. Giroud, F.; Minteer, S.D. Anthracene-Modified Pyrenes Immobilized on Carbon Nanotubes for Direct Electroreduction of $\mathrm{O}_{2}$ by Laccase. Electrochem. Commun. 2013, 34, 157-160. [CrossRef]

60. Bourourou, M.; Elouarzaki, K.; Lalaoui, N.; Agnès, C.; Le Goff, A.; Holzinger, M.; Maaref, A.; Cosnier, S. Supramolecular Immobilization of Laccase on Carbon Nanotube Electrodes Functionalized with (Methylpyrenylaminomethyl) Anthraquinone for Direct Electron Reduction of Oxygen. Chemistry 2013, 19, 9371. [CrossRef]

61. Lalaoui, N.; Elouarzaki, K.; Le Goff, A.L.; Holzinger, M.; Cosnier, S. Efficient Direct Oxygen Reduction by Laccases Attached and Oriented on Pyrene-Functionalized Polypyrrole/Carbon Nanotube Electrodes. Chem. Commun. 2013, 49, 9281. [CrossRef]

62. Lalaoui, N.; David, R.; Jamet, H.; Holzinger, M.; Le Goff, A.; Cosnier, S. Hosting Adamantane in the Substrate Pocket of Laccase: Direct Bioelectrocatalytic Reduction of $\mathrm{O}_{2}$ on Functionalized Carbon Nanotubes. ACS Catal. 2016, 6, 4259. [CrossRef] 
63. Bollella, P.; Hibino, Y.; Kano, K.; Gorton, L.; Antiochia, R. Enhanced Direct Electron Transfer of Fructose Dehydrogenase Rationally Immobilized on a 2-Aminoanthracene Diazonium Cation Grafted Single-Walled Carbon Nanotube Based Electrode. ACS Catal. 2018, 8, 10279. [CrossRef]

64. Gentil, S.; Che Mansor, S.M.C.; Jamet, H.; Cosnier, S.; Cavazza, C.; Le Goff, A. Oriented Immobilization of [NiFeSe] Hydrogenases on Covalently and Noncovalently Functionalized Carbon Nanotubes for $\mathrm{H}_{2} / \mathrm{Air}$ Enzymatic Fuel Cells. ACS Catal. 2018, 8, 3957. [CrossRef]

65. So, K.; Kawai, S.; Hamano, Y.; Kitazumi, Y.; Shirai, O.; Hibi, M.; Ogawa, J.; Kano, K. Improvement of a Direct Electron Transfer-Type Fructose/Dioxygen Biofuel Cell with a Substrate-Modified Biocathode. Phys. Chem. Chem. Phys. PCCP 2014, 16, 4823. [CrossRef] [PubMed]

66. Matanovic, I.; Babanova, S.; Chavez, M.S.; Atanassov, P. Protein-Support Interactions for Rationally Designed Bilirubin Oxidase Based Cathode: A Computational Study. J. Phys. Chem. B 2016, 120, 3634. [CrossRef]

67. Lopez, R.J.; Babanova, S.; Ulyanova, Y.; Singhal, S.; Atanassov, P. Improved Interfacial Electron Transfer in Modified Bilirubin Oxidase Biocathodes. ChemElectroChem 2014, 1, 241-248. [CrossRef]

68. Ulyanova, Y.; Babanova, S.; Pinchon, E.; Matanovic, I.; Singhal, S.; Atanassov, P. Effect of Enzymatic Orientation through the Use of Syringaldazine Molecules on Multiple Multi-Copper Oxidase Enzymes. Phys. Chem. Chem. Phys. PCCP 2014, 16, 13367. [CrossRef]

69. Lalaoui, N.; Le Goff, A.; Holzinger, M.; Cosnier, S. Fully Oriented Bilirubin Oxidase on Porphyrin-Functionalized Carbon Nanotube Electrodes for Electrocatalytic Oxygen Reduction. Chemistry 2015, 21, 16868. [CrossRef]

70. Xia, H.-Q.; Hibino, Y.; Kitazumi, Y.; Shirai, O.; Kano, K. Interaction between D-Fructose Dehydrogenase and Methoxy-Substituent-Functionalized Carbon Surface to Increase Productive Orientations. Electrochim. Acta 2016, 218, 41-46. [CrossRef]

71. Sakai, K.; Kitazumi, Y.; Shirai, O.; Takagi, K.; Kano, K. Direct Electron Transfer-Type Four-Way Bioelectrocatalysis of $\mathrm{CO}_{2}$ /Formate and $\mathrm{NAD}^{+} / \mathrm{NADH}$ Redox Couples by Tungsten-Containing Formate Dehydrogenase Adsorbed on Gold Nanoparticle-Embedded Mesoporous Carbon Electrodes Modified with 4-Mercaptopyridine. Electrochem. Commun. 2017, 84, 75-79. [CrossRef]

72. Al-Lolage, F.A.; Bartlett, P.N.; Gounel, S.B.; Staigre, P.; Mano, N. Site-Directed Immobilization of Bilirubin Oxidase for Electrocatalytic Oxygen Reduction. ACS Catal. 2019, 9, 2068. [CrossRef]

73. Lalaoui, N.; Rousselot-Pailley, P.; Robert, V.; Mekmouche, Y.; Villalonga, R.; Holzinger, M.; Cosnier, S.; Tron, T.; Le Goff, A. Direct Electron Transfer between a Site-Specific Pyrene-Modified Laccase and Carbon Nanotube/Gold Nanoparticle Supramolecular Assemblies for Bioelectrocatalytic Dioxygen Reduction. ACS Catal. 2016, 6, 1894. [CrossRef]

74. Gentil, S.; Rousselot-Pailley, P.; Sancho, F.; Robert, V.; Mekmouche, Y.; Guallar, V.; Tron, T.; Le Goff, A. Efficiency of Site-Specific Clicked Laccase-Carbon Nanotubes Biocathodes towards $\mathrm{O}_{2}$ Reduction. Chemistry 2020, 26, 4798. [CrossRef] [PubMed]

75. Dagys, M.; Laurynėnas, A.; Ratautas, D.; Kulys, J.; Vidžiūnaitė, R.; Talaikis, M.; Niaura, G.; Marcinkevičienè, L.; Meškys, R.; Shleev, S. Oxygen Electroreduction Catalysed by Laccase Wired to Gold Nanoparticles via the Trinuclear Copper Cluster. Energy Environ. Sci. 2017, 10, 498-502. [CrossRef]

76. Yang, S.; Liu, J.; Quan, X.; Zhou, J. Bilirubin Oxidase Adsorption onto Charged Self-Assembled Monolayers: Insights from Multiscale Simulations. Langmuir 2018, 34, 9818. [CrossRef]

77. Hexter, S.V.; Grey, F.; Happe, T.; Climent, V.; Armstrong, F.A. Electrocatalytic Mechanism of Reversible Hydrogen Cycling by Enzymes and Distinctions between the Major Classes of Hydrogenases. Proc. Natl. Acad. Sci. USA 2012, 109, 11516. [CrossRef]

78. Fourmond, V.; Léger, C. Modelling the Voltammetry of Adsorbed Enzymes and Molecular Catalysts. Curr. Opin. Electrochem. 2017, 1, 110. [CrossRef]

79. Kornienko, N.; Ly, K.H.; Robinson, W.E.; Heidary, N.; Zhang, J.Z.; Reisner, E. Advancing Techniques for Investigating the Enzyme-Electrode Interface. Acc. Chem. Res. 2019, 52, 1439. [CrossRef]

80. Sauerbrey, G. Verwendung von Schwingquarzen zur Wägung Dünner Schichten und zur Mikrowägung. Z. Phys. 1959, 155, 206. [CrossRef]

81. Singh, K.; Blanford, C.F. Electrochemical Quartz Crystal Microbalance with Dissipation Monitoring: A Technique to Optimize Enzyme Use in Bioelectrocatalysis. ChemCatChem 2014, 6, 921-929. [CrossRef] 
82. Tahar, A.B.; Żelechowska, K.; Biernat, J.F.; Paluszkiewicz, E.; Cinquin, P.; Martin, D.; Zebda, A. High Catalytic Performance of Laccase Wired to Naphthylated Multiwall Carbon Nanotubes. Biosens. Bioelectron. 2020, 151, 111961. [CrossRef] [PubMed]

83. Kong, J.; Yu, S. Fourier Transform Infrared Spectroscopic Analysis of Protein Secondary Structures. Acta Biochim. Biophys. Sin. 2007, 39, 549-559. [CrossRef] [PubMed]

84. Wu, F.; Su, L.; Yu, P.; Mao, L. Role of Organic Solvents in Immobilizing Fungus Laccase on Single-Walled Carbon Nanotubes for Improved Current Response in Direct Bioelectrocatalysis. J. Am. Chem. Soc. 2017, 139, 1565. [CrossRef] [PubMed]

85. Han, Z.J.; Zhao, L.J.; Yu, P.; Chen, J.W.; Wu, F.; Mao, L.Q. Comparative Investigation of Small Laccase Immobilized on Carbon Nanomaterials for Direct Bioelectrocatalysis of Oxygen Reduction. Electrochem. Commun. 2019, 101, 82-87. [CrossRef]

Publisher's Note: MDPI stays neutral with regard to jurisdictional claims in published maps and institutional affiliations.

(C) 2020 by the authors. Licensee MDPI, Basel, Switzerland. This article is an open access article distributed under the terms and conditions of the Creative Commons Attribution (CC BY) license (http://creativecommons.org/licenses/by/4.0/). 